Article

\title{
Pastoral Population Growth and Land Use Policy Has Significantly Impacted Livestock Structure in Inner Mongolia-A Case Study in the Xilinhot Region
}

\author{
Ye Jiang ${ }^{1,2}$, Qing Zhang ${ }^{1,3}$, Jianming Niu ${ }^{1,3}$ and Jianguo $\mathrm{Wu}^{4, *}$ \\ 1 School of Ecology and Environment, Inner Mongolia University, Hohhot 010021, China; \\ jiangye@ibcas.ac.cn (Y.J.); qzhang82@imu.edu.cn (Q.Z.); jmniu2005@163.com (J.N.) \\ 2 State Key Laboratory of Vegetation and Environmental Change, Institute of Botany, Chinese Academy \\ of Sciences, Beijing 100093, China \\ 3 Ministry of Education Key Laboratory of Ecology and Resource Use of the Mongolian Plateau \& \\ Inner Mongolia Key Laboratory of Grassland Ecology, Hohhot 010021, China \\ 4 School of Life Sciences and School of Sustainability, Arizona State University, Tempe, AZ 85287, USA \\ * Correspondence: Jingle.Wu@asu.edu
}

Received: 10 October 2019; Accepted: 12 December 2019; Published: 16 December 2019

\begin{abstract}
The traditional livestock industry in Inner Mongolia has evolved rapidly in response to social and economic transformations during recent decades, resulting in substantial impacts on the rural economy and livelihoods of pastoralists. Improved understanding of these changes and potential drivers may help foster strategies to sustain the pastoral system of this region. Using long-term climate, social-economic, and livestock (cattle, horses, sheep, and goats) population data from 1970 to 2010, we analyzed the dynamics of the livestock industry and main driving factors in the Xilinhot region-a central part of the Inner Mongolia Grassland. Our results show that the total livestock population increased dramatically in the past four decades, especially during 1987-2010. Livestock composition also changed substantially, with increasing sheep, goat, and cattle populations but a decreasing horse population. Pastoral population growth and land use policy were the primary drivers for livestock dynamics during 1970-2010. Livestock structure became differentiated progressively with changes in land use policy. Also, climate factors had an important influence on livestock production. The current study suggests that sustainable animal husbandry in this region requires government policies that promote ecological urbanization, livestock production efficiency, incentive systems for grassland conservation, and collective action and cooperation for enhancing social capital and resilience.
\end{abstract}

Keywords: grassland sustainability; livestock composition; pastoral population; land use policy; Inner Mongolia

\section{Introduction}

Livestock have played a significant role in different stages of human development, evolving from primitive nomadism to herding for survival, and to breeding and selling for diversified demands in modern commercial society [1]. As social transformation occurs over time and space, the social and economic functions of livestock have also changed [2]. Livestock husbandry has been an important industry in a number of continents and regions, such as the Mongolia Plateau, Africa, Australia, and New Zealand [3,4], and crucial to supporting global food security, as it supplies $17 \%$ of the kilocalories and $33 \%$ of their protein consumption, globally [5]. Furthermore, livestock are crucial for the livelihoods of around one billion poor people in the world [6], $80 \%$ of whom inhabit remote and undeveloped areas and procure sustainable livelihoods mainly by livestock farming [7]. By all 
accounts, livestock production has made a prominent contribution to improving remote livelihoods and alleviating poverty for pastoralists, especially those living in the arid and semi-arid regions $[8,9]$.

Many studies have documented that livestock are impacted by climate and altered rainfall [10], increased temperatures [11], frequent drought and bush encroachment [12], extreme events like snow storms and drought damage [13], and competition for diminished grassland resources [14]. The impacts of climate change on livestock are also well described in terms of forage yield, thermal stress, water supply, epidemic disease expansion, as well as loss of biodiversity and production systems [8]. For example, changes in $\mathrm{CO}_{2}$ concentration and temperature directly impact plant growth through impacting herbage production, yield, and composition, and recurrent drought often limits dry matter production in herbage [15]. Livestock are vulnerable to heat stress in wet and warm environments, which can modify behavioral and metabolic performances, further negatively influencing animal feed intake and productivity [16]. High temperatures are considered favorable for the growth of viruses or parasites, subsequently causing the spread of various animal diseases [17]. According to the report by the UN Intergovernmental Panel on Climate Change (IPCC) [18], many plants and animals will be at a risk of genetic diversity losses due to climate change, in particular, a rise in temperature. There is a large body of research suggesting that climate hazard and variation can be expected to bring about numerous adverse impacts on livestock production, which will be more severe and pressing for pastoralism characterized by practicing in vast marginal lands across the world [19].

In addition, livestock development is also greatly influenced by complex interplay between social and economic factors. Steinfeld et al. [20] categorized increases in human population, economic growth, urbanization, dietary adjustments, and land use change as major global drivers. Specifically, the world's population growth and economic expansion have significantly increased human demand and consumption for animal products. The changing population structure has contributed to this growth in that urbanization leads to a dietary transition to more animal-origin food, and pastoral population is perceived as closely related to the total herd size [3]. Global escalating demands for livestock products have pushed producers to enlarge animal and feed production in the face of decreasing available lands, resulting in land use changes, such as reclaiming, abandoning, and overgrazing grasslands, all of which may in turn impact the production and development of animal husbandry [20]. Meanwhile, factors affecting livestock husbandry may vary dramatically on different temporal and spatial scales. For instance, Megersa et al. [12] reported that inadequate knowledge for raising camel, stocking costs, and insufficient labor hindered the adoption of livestock diversification in southern Ethiopia during 1976 and 2011. Growing demand for cashmere in Mongolia stimulated the rise in goat numbers in the period of 1992-2006 [21], whereas animal overstocks and insufficient government support were thought to be major problems for Mongolia's subsistence livestock herding [13]. Li et al. [22] discussed the influence of economic improvement, income increase, and urbanization on the development of China's animal husbandry, with a dichotomy in production systems between the eastern and western regions of China [4].

At the regional scale (e.g., Inner Mongolia, Southern Europe), Li et al. found that a lack of traditional grassland management or malpractices during the social movement period of 1964-1978 severely impacted the nomadic livestock industry in Inner Mongolia of China, which increased the vulnerability of livestock to climate risks [19]. The rural depopulation in Southern Europe in the late 2000s, encouraged by economic growth and agricultural policies, greatly promoted a shift from traditional livestock production to production with a higher level of specialization [23]. Government policies and booming demand for beef were observed to drive a high rate of deforestation and the associated cattle ranching in Brazil and Costa Rica over the period of 1990-2008 [4], causing serious problems involving the environment, climate change, and rural livelihoods. Denmark is reported to have excelled in the European Union in implementing elaborately designed measures since 1985, which helps reduce $\mathrm{N}$ surpluses and $\mathrm{N}$ losses in the intensive livestock system, further increasing $\mathrm{N}$ efficiency [4]. 
Inner Mongolia has a long history of exercising traditional nomadic pastoralism and remains an important livestock production base in China [24]. The 78 million hectares of natural grasslands in Inner Mongolia make up nearly a quarter of the total grassland area in China and provide valuable ecosystem services for the region as well as the nation [25]. In spite of substantial improvements in livestock productivity and herders' standards of living over the past few decades, it is widely acknowledged that the Inner Mongolia grassland has been suffering degradation to varying extent, resulting in decreased grassland productivity and intensified conflicts over pastoralism development [26,27]. Poor grazing management, irrational livestock structure, and herders' single source of income [28] have combined to restrain the animal husbandry industry and local pastoralists from further development. Focusing on the Xilinhot region, the central part of the Inner Mongolian Grassland, this study was designed to quantify the dynamics of the livestock industry from 1970 to 2010 and identify the underlying environmental and socioeconomic drivers. Based on the above analysis, we also aimed to provide suggestions for improving management schemes and livelihood strategies in the Xilinhot grassland, so as to promote regional sustainability.

\section{Study Area}

The Xilinhot grassland, in the core area in Eurasian steppe, is located in the Inner Mongolia Autonomous Region, China $\left(43^{\circ}-45^{\circ} \mathrm{N}, 115^{\circ}-118^{\circ} \mathrm{E}\right.$ ) and covers approximately $15,000 \mathrm{~km}^{2}$ (Figure 1 ). The study area is relatively flat and decreases from East to West, with an average elevation of $1250 \mathrm{~m}$. Long-term (1970-2010), the air temperature was $2.78{ }^{\circ} \mathrm{C}$, ranging from $-22.95^{\circ} \mathrm{C}$ in January to $24.94{ }^{\circ} \mathrm{C}$ in July. Long-term annual precipitation was $269.3 \mathrm{~mm}$, about $68.6 \%$ in the growing season (from June to August). $C_{3}$ perennial rhizome grass, Leymus chinensis, and $C_{3}$ perennial grass, Stipa grandis, co-dominate in the plant community, and are widely distributed in the eastern Eurasian steppe. This area plays a central role for sustaining the livestock industry of northern China [29]. Local domestic livestock include sheep, goat, cattle, horse, donkey, mule, and camel, and have supported the pastoral livelihoods over centuries. However, in recent years, land tenure alteration, animal overstock, grassland degradation, climate change, and poor grazing practices have increasingly brought challenges and risks to this traditional livelihood.

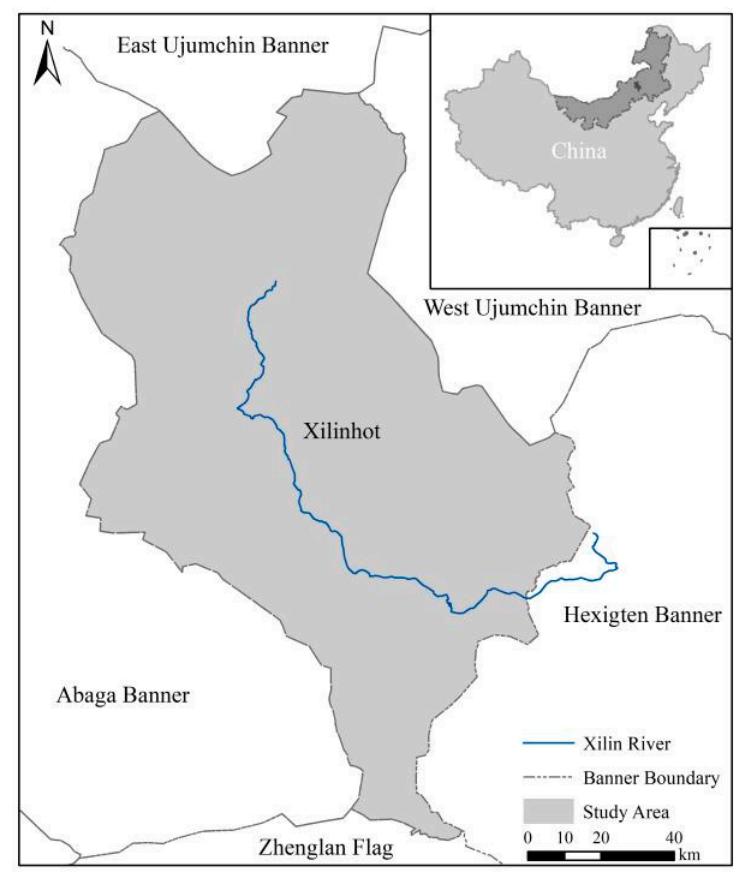

Figure 1. Location of the study site. 


\section{Methods}

Long-term domestic livestock data sets from 1970 to 2010 were collected to analyze changes in livestock population and composition in the Xilinhot grassland. The livestock species in our study area included cattle, horse, donkey, mule, camel, sheep, and goat-the first five species of which are large animals, the remaining two are small animals. Based on Chinese animal husbandry development [30] and evolving regional grassland policies [31,32], the pastoral history of the Xilinhot grassland between 1970 and 2010 is divided roughly into three stages, the last nomadic period (1970-1986) [33,34], fast development period (1987-2000), and ecological recovery period (2001-2010) [35]. The characteristics of socioeconomic status, land use policies, and grazing managements in three main periods during 1970-2010 are listed in Table 1 [36-38]. The data covering climatic factors (temperature and precipitation), urban and pastoral population, and land use policy (categorized variables, 1, 2, 3), basically reflect changes in climate, socio-economic, and grassland policy aspects during the past 40 years, which were used to detect the impacts of climate change, human demand, and land use policy on grassland animal husbandry in the three periods. The data sets were obtained from the annual statistical census of Xilingol Leagure, Inner Mongolia, China, except for data on air temperature and precipitation, which were accessed from China Meteorological Data Sharing Service System.

Table 1. Characteristics of land use policies in three periods during 1970-2010 in Xilinhot, Inner Mongolia, China.

\begin{tabular}{|c|c|c|c|}
\hline $\begin{array}{l}\text { Herding Management } \\
\text { System }\end{array}$ & $\begin{array}{c}\text { Last Nomadic Period } \\
(1970-1986)\end{array}$ & $\begin{array}{c}\text { Fast Development Period } \\
(1987-2000)\end{array}$ & $\begin{array}{l}\text { Ecological Recovery } \\
\text { Period (2001-2010) }\end{array}$ \\
\hline Period & The people's commune & The socialist period & The socialist period \\
\hline Economic system & Planned economy & Market economy & $\begin{array}{l}\text { Market economy with rapid } \\
\text { development of industrial } \\
\text { economy }\end{array}$ \\
\hline Land use institution & $\begin{array}{l}\text { Collective management } \\
\text { and use of grassland }\end{array}$ & $\begin{array}{l}\text { Privatization of land use } \\
\text { rights }\end{array}$ & Privatization of land use rights \\
\hline Grazing regime & $\begin{array}{c}\text { Nomadic } \\
\text { grazing/semi-nomadic } \\
\text { and semi-settled } \\
\text { grazing/fixed grazing }\end{array}$ & Permanent grazing & $\begin{array}{l}\text { Permanent grazing/conducting } \\
\text { scientific grazing system in } \\
\text { some areas }\end{array}$ \\
\hline Basic business unit & People's communes & Family household & $\begin{array}{l}\text { Individual household/ } \\
\text { co-management by small-group } \\
\text { households }\end{array}$ \\
\hline Grazing management & Collectively managed & Individual decision-making & Individual decision-making \\
\hline $\begin{array}{l}\text { Restrained measures in } \\
\text { management }\end{array}$ & Yes & No & $\begin{array}{l}\text { Yes (administrative control } \\
\text { measures in the ecological } \\
\text { programs areas) }\end{array}$ \\
\hline Ecological programs & No & No & Yes (ecological recovery programs) \\
\hline Allocation mechanism & $\begin{array}{l}\text { Allocated by the } \\
\text { collectives }\end{array}$ & $\begin{array}{l}\text { Self-management/ assume } \\
\text { responsibility for profits and } \\
\text { losses on one's own }\end{array}$ & $\begin{array}{l}\text { Self-management/ assume } \\
\text { responsibility for profits and } \\
\text { losses on one's own }\end{array}$ \\
\hline $\begin{array}{l}\text { Source of income of } \\
\text { herdsmen }\end{array}$ & Single & Single & $\begin{array}{c}\text { Diversified (selling } \\
\text { livestock/ecological award/ } \\
\text { engaging in service industry) }\end{array}$ \\
\hline $\begin{array}{l}\text { Number of livestock per } \\
\text { capita (Mean } \pm \text { SE) }\end{array}$ & $116 \pm 28$ & $169 \pm 25$ & $151 \pm 13$ \\
\hline
\end{tabular}

SE represents standard error.

In our data analysis, each cattle, horse, donkey, mule, camel, and goat was treated as 5, 6, 3, 3, 7, and 0.9 sheep units [39]. The sheep units were summed from seven species' populations for the total livestock population for each year. Based on these sheep units, we calculated the livestock population of four dominant species (e.g., cattle, horse, sheep, and goat). We did not calculate the livestock population of donkey, mule, and camel due to their small population number. For the livestock groups 
(e.g., large and small livestock) and four dominant species, we calculated their proportion of the total sheep unit as their livestock composition for each year. We used trend analysis to detect the livestock number and livestock composition over the years in each period (from 1970 to 2010) separately.

In addition, multiple regression models were constructed to analyze driving forces that affected the livestock population and composition during the past 40 years in three sub-periods, including 1970-1986, 1987-2000, and 2001-2010, separately. We treated the total livestock population, the four dominant species' (e.g., cattle, horse, sheep, and goat) populations, the large livestock and small livestock composition, and four dominant species' compositions as dependent variables. Besides this, we used all the important predictors, including environmental, socioeconomic, and policy indicators, listed in Table 2 in our models as independent variables. Multiple linear regressions with stepwise variable selection (forward and backward) were used to determine the effects of predictors on the dependent variable. Partial $\mathrm{R}^{2}$ was used to present the explainable power of the significant predictors for each variable [40]. Trend analysis and the multivariate regression model were performed using the SigmaPlot 10.0 software and the SAS@ 8.1. software (The SAS Institute Inc., Cary, NC, USA), respectively.

Table 2. Potential driving forces and their environmental, socioeconomic, and policy indicators used as predictor variables in this study in Xilinhot, Inner Mongolia, China.

\begin{tabular}{cccc}
\hline Driving Forces & Factor/Indicator Applied & Abbreviation & Unit \\
\hline & Annual average temperature & AVTEM & ${ }^{\circ} \mathrm{C}$ \\
& Winter mean temperature & WMTEM & ${ }^{\circ} \mathrm{C}$ \\
& Non-winter mean temperature & NWMTEM & ${ }^{\circ} \mathrm{C}$ \\
Environmental aspect & Extremely high temperature & EXHTEM & ${ }^{\circ} \mathrm{C}$ \\
& Extremely cold temperature & EXCTEM & ${ }^{\circ} \mathrm{C}$ \\
& Drought index & DRINDEX & - \\
& Winter snowfall & WSNOW & $\mathrm{mm}$ \\
\hline \multirow{2}{*}{ Socioeconomic aspect } & Urban population & URBPOPU & Person \\
& Pastoral population & PASPOPU & Person \\
\hline Local policy aspect & Land use policy & LANDUC & - \\
\hline
\end{tabular}

\section{Results}

\subsection{Changes in Livestock Population}

Total livestock populations (sheep unit) in Xilinhot showed a significant increasing trend across 1970-2010 and rose by nearly five times relative to that in 1970 (Figure 2a). The increasing rate was highest for the fast development period (1987-2000, Figure 2a; $p<0.001)$ and lowest for the last nomadic period (1970-1986, Figure 2a; $p<0.001)$. The total numbers peaked in 1999 and declined by 38\% from 2000, from 2.26 million sheep units in 1999 to 1.39 million sheep units in 2010 (Figure 2a).

Large livestock experienced an upward trend over the past four decades, with the totals doubled (Figure $2 b$ ). The number of cattle exhibited a consistent trend with large animals (Figure 2d), whereas the horse number increased from the beginning to the summit in $1980(p=0.003)$ and then dropped gradually to the lowest point in the ecological recovery period of 2001-2010 (Figure 2e).

Population in small livestock boomed and increased almost nine-fold over the entire study period. It showed a significant growth for the two earlier periods and a decreasing trend for the last period (Figure 2c). Sheep density accounted for the majority among small livestock and averaged approximately $83 \%$ over the past four decades (Figure 2f), suggesting the changes in small livestock population were mainly mediated by sheep intensity. Both sheep (Figure 2f) and goat population (Figure 2g) showed a similar changing trend from 1970 to 2010, with a minor difference that the increase in goat population was greater than that of sheep after 2000 (Figure $2 \mathrm{~g} ; p=0.006$ ). 


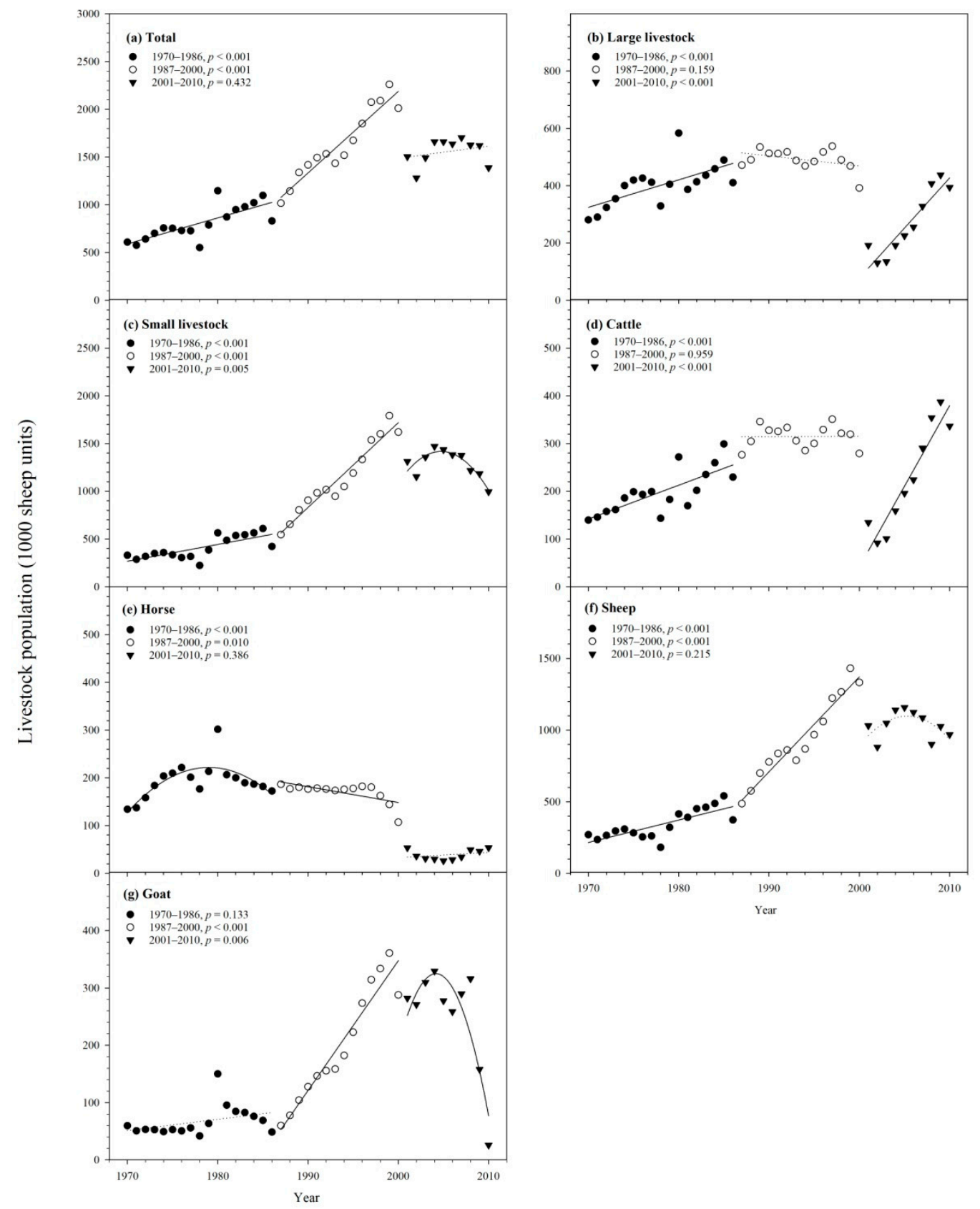

Figure 2. Changes in livestock population (sheep unit) in Xilinhot from 1970 to 2010. (a) Total, (b) Large livestock, (c) Small livestock, (d) Cattle, (e) Horse, (f) Sheep, (g) Goat. The three sub-periods are illustrated as 1970-1986(•), 1987-2000 (○), and 2001-2010(v).

\subsection{Changes in Large and Small Livestock as well as Species Proportion}

The proportion of large livestock in total sheep units increased from the early 1970s to 1978, when it reached the maximum (about 60\%, Figure 3a), while that of small livestock grew dramatically since then on until 2003, when it attained the highest value (about 90\%, Figure 3b). Another upward trend emerged in large livestock proportion between 2004 and 2010 (Figure 3a; $p<0.001$ ), which accounted for $28.3 \%$ in total sheep units in 2010 (Figure 3a). Overall, the proportion of large and small livestock on average constituted $35.9 \%$ and $64.1 \%$ of total animals across $1970-2010$, respectively, indicating that small animals contributed more to the totals than large animals (Figure 3). 


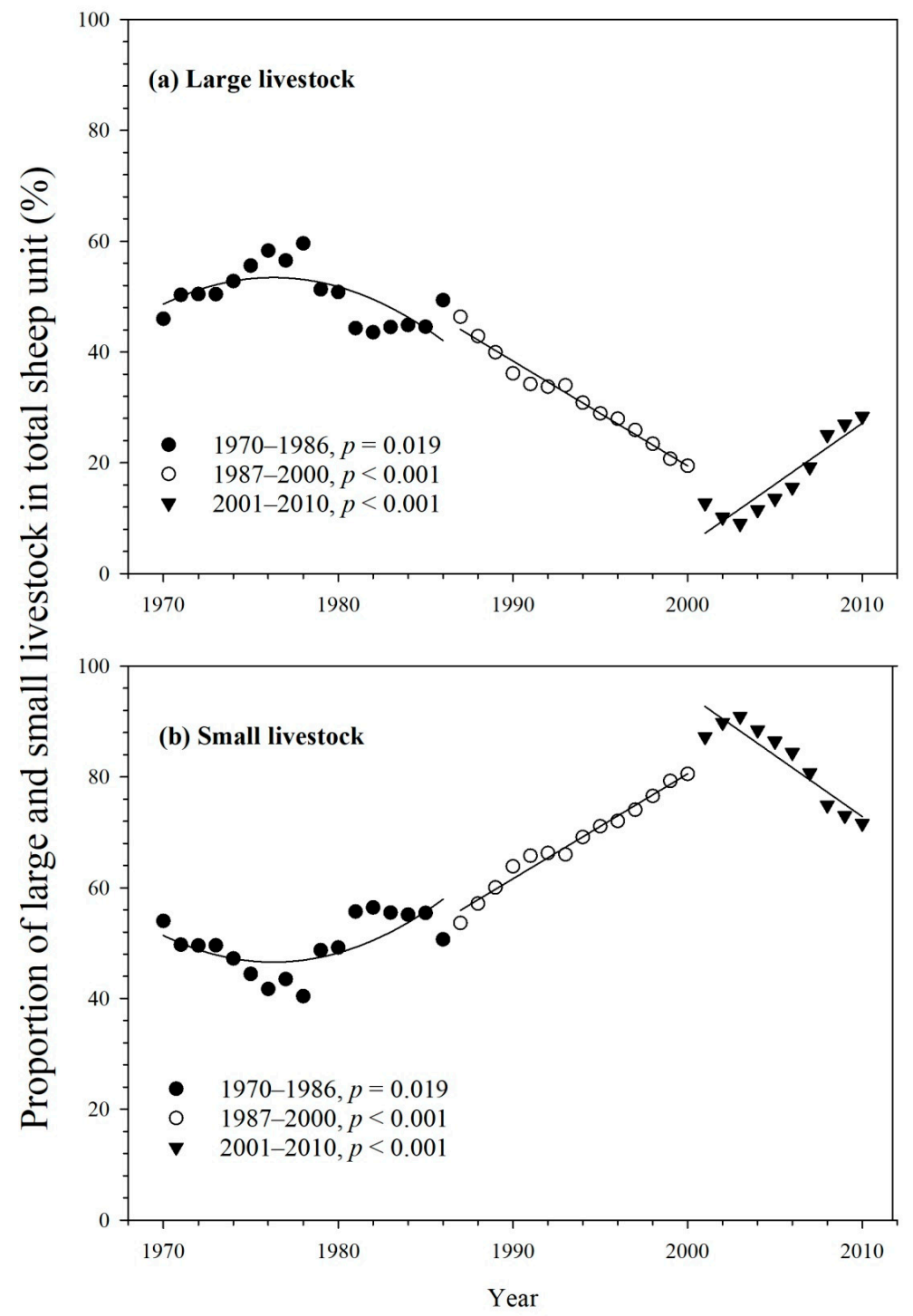

Figure 3. Changes in large and small livestock proportion in sheep unit across 1970-2010. (a) Large livestock, (b) small livestock. The three sub-periods are illustrated as 1970-1986 (•), 1987-2000 (○), and 2001-2010 ( $\mathbf{v})$.

As shown in Figure 4, the proportion of cattle did not show a statistically significant change in the last nomadic period (Figure 4a; $p=0.699$ ), while that of horse increased and then declined with the maximum averaging 32\% in total sheep units (Figure $4 b ; p<0.001$ ). During the period from 1987 to 2000 , the proportion of both cattle $(p<0.001)$ and horse $(p<0.001)$ showed a consistent decreasing trend with large livestock (Figure 3a). The last period, from 2001 to 2010, witnessed an increase and a low level kept in the cattle $(p<0.001)$ and horse proportion $(p=0.584)$, respectively.

With respect to small livestock, the change in the proportion of sheep and goat showed similar patterns, over the past 40 years (Figure 4c,d). 

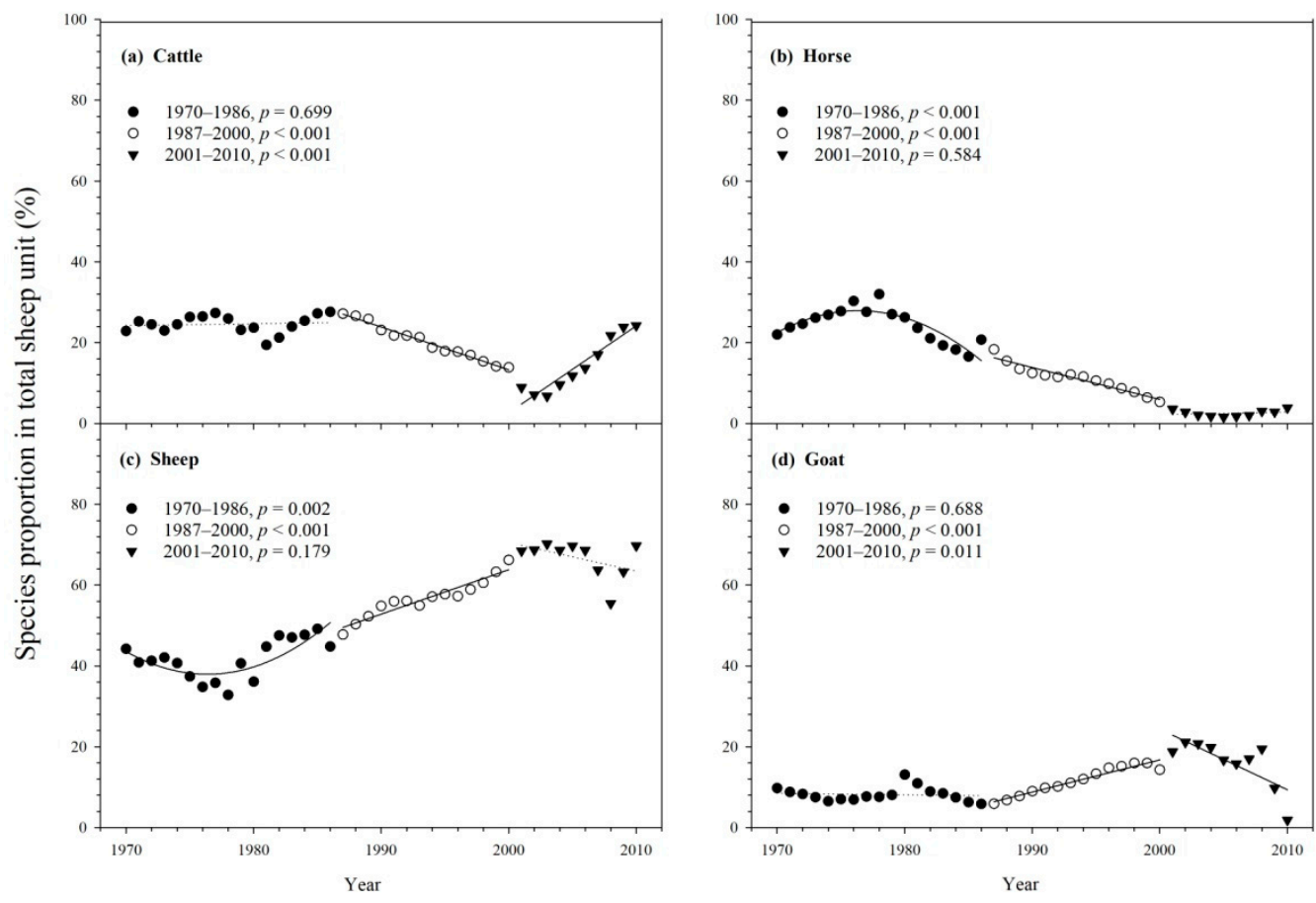

Figure 4. Changes in livestock species proportion in sheep unit across 1970-2010. (a) Cattle, (b) horse, (c) sheep, and (d) goat. The three sub-periods are illustrated as 1970-1986 (•), 1987-2000 (○), and 2001-2010 $(\mathbf{v})$.

\subsection{Factors Driving Changes in Total Livestock and Species Population over the Past 40 Years}

The results showed that pastoral population had a significant impact on the changes in total livestock populations between 1970-2010 $\left(R^{2}=0.76\right.$, Table 3$)$, with factors varying considerably among the three sub-periods. Urban population in Xilinhot $\left(R^{2}=0.54\right)$ and pastoral population $\left(R^{2}=0.88\right)$ were cited as dominant driving factors in the last nomadic period and the fast development period, respectively. No factor, however, was observed among the analyzed predictors in the last period from 2001 onward.

Large livestock's population change from 1970 to 2010 was caused by changes in urban population $\left(R^{2}=0.29\right.$, Table 3$)$ and land use policy $\left(R^{2}=0.13\right)$, in which land use policy was negatively correlated with the change, while pastoral population was analyzed as a leading cause of change in small livestock population in both the $1970-2010$ period $\left(R^{2}=0.80\right)$ and the $1987-2000$ period $\left(R^{2}=0.89\right)$. As for the remaining two periods (1970-1986 and 2001-2010), urban population $\left(R^{2}=0.48\right)$ and environmental predictor represented by extremely high temperature $\left(R^{2}=0.48\right)$ were critical factors for the trend of change in small animals.

When examined over the changes in the four major livestock species, we found that the two factors mostly impacting that of cattle from 1970 to 2010 were pastoral $\left(R^{2}=0.23\right)$ and urban population $\left(R^{2}=0.15\right)$, and urban population alone was detected as the leading cause for the two periods of $1970-1986\left(R^{2}=0.55\right)$ and $2001-2010\left(R^{2}=0.75\right)$. The predictors presented in Table 3 did not have a marked influence on the cattle change in the fast development period. Land use policy had significant effects on the trend of change in horse population over the entire study period, showing a strong, negatively linear relationship between them $\left(R^{2}=0.71\right)$. The environmental indicators, like drought index $\left(R^{2}=0.26\right)$ and non-winter mean temperature $\left(R^{2}=0.58\right)$, were detected as the major factors for the two earlier periods. In terms of small livestock, pastoral population significantly impacted the change in sheep $\left(R^{2}=0.83\right)$ and goat dynamics $\left(R^{2}=0.57\right)$ from 1970 to 2010 . It is interesting to note that environmental factors had more influence on the change in goat population compared with that in sheep population, both for the entire study period and for different sub-periods (Table 3). 
Table 3. Driving force analysis of livestock population change in three periods during 1970-2010 in Xilinhot, Inner Mongolia, China.

\begin{tabular}{|c|c|c|c|c|c|c|c|c|c|c|c|c|}
\hline \multirow[b]{2}{*}{ Response } & \multicolumn{3}{|c|}{ 1970-1986 } & \multicolumn{3}{|c|}{ 1987-2000 } & \multicolumn{3}{|c|}{ 2001-2010 } & \multicolumn{3}{|c|}{ 1970-2010 } \\
\hline & Predictor & Partial $R^{2}$ & Effect & Predictor & Partial $R^{2}$ & Effect & Predictor & Partial $R^{2}$ & Effect & Predictor & Partial $R^{2}$ & Effect \\
\hline Total & URBPOPU ${ }^{2}$ & $0.54^{* * *}$ & + & PASPOPU $^{2}$ & $0.88^{* * *}$ & + & & & & PASPOPU $^{2}$ & $0.76^{* * *}$ & + \\
\hline livestock & DRINDEX $^{1}$ & $0.18^{* *}$ & + & & & & & & & AVTEM $^{1}$ & $0.05^{* *}$ & + \\
\hline Large & URBPOPU ${ }^{2}$ & $0.45^{* *}$ & + & NWMTEM $^{1}$ & 0.37 * & - & URBPOPU ${ }^{2}$ & $0.70^{* *}$ & + & URBPOPU 2 & $0.29 * * *$ & + \\
\hline livestock & DRINDEX $^{1}$ & $0.19 *$ & + & AVTEM $^{1}$ & $0.25 *$ & + & NWMTEM $^{1}$ & $0.19^{* *}$ & + & LANDUC $^{3}$ & 0.13 * & - \\
\hline Small & URBPOPU $^{2}$ & $0.48^{* *}$ & + & PASPOPU $^{2}$ & $0.89 * * *$ & + & EXHTEM $^{2}$ & $0.48^{*}$ & - & PASPOPU $^{2}$ & $0.79^{* * *}$ & + \\
\hline livestock & DRINDEX $^{1}$ & 0.14 * & + & & & & & & & AVTEM $^{1}$ & $0.05^{* * *}$ & + \\
\hline \multirow{3}{*}{ Cattle } & URBPOPU ${ }^{2}$ & $0.55^{* * *}$ & + & & & & URBPOPU ${ }^{2}$ & $0.75^{* *}$ & + & PASPOPU $^{2}$ & $0.23^{* *}$ & + \\
\hline & WMTEM $^{1}$ & 0.15 * & - & & & & NWMTEM $^{1}$ & $0.16^{* *}$ & + & URBPOPU 2 & $0.15^{* *}$ & + \\
\hline & DRINDEX $^{1}$ & 0.26 * & + & NWMTEM $^{1}$ & $0.58^{* *}$ & - & & & & LANDUC $^{3}$ & $0.71^{* * *}$ & - \\
\hline \multirow[t]{2}{*}{ Horse } & & & & WMTEM $^{1}$ & $0.24^{* *}$ & + & & & & EXCTEM $^{1}$ & $0.06^{* *}$ & + \\
\hline & & & & & & & & & & URBPOPU $^{2}$ & $0.03 *$ & + \\
\hline \multirow{4}{*}{ Sheep } & URBPOPU $^{2}$ & $0.54^{* * *}$ & + & PASPOPU $^{2}$ & $0.88^{* * *}$ & + & & & & PASPOPU $^{2}$ & $0.83^{* * *}$ & + \\
\hline & WMTEM $^{1}$ & 0.13 * & - & & & & & & & AVTEM $^{1}$ & $0.04^{* *}$ & + \\
\hline & DRINDEX $^{1}$ & $0.55^{* * *}$ & + & PASPOPU ${ }^{2}$ & $0.90^{* * *}$ & + & EXCTEM $^{1}$ & $0.66^{* *}$ & + & PASPOPU $^{2}$ & $0.57^{* * *}$ & + \\
\hline & & & & & & & WSNOW $^{1}$ & $0.16^{*}$ & - & AVTEM $^{1}$ & $0.10^{* *}$ & + \\
\hline \multirow[t]{3}{*}{ Goat } & & & & & & & NWMTEM $^{1}$ & $0.08^{* *}$ & - & EXHTEM $^{1}$ & $0.03 *$ & - \\
\hline & & & & & & & PASPOPU $^{2}$ & $0.01 *$ & + & DRINDEX $^{1}$ & 0.03 * & + \\
\hline & & & & & & & AVTEM $^{1}$ & 0.0004 * & + & & & \\
\hline
\end{tabular}

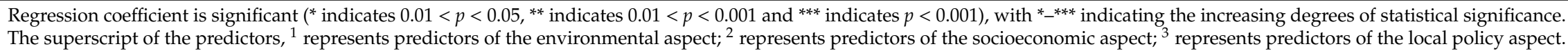
The symbol " + " indicates significant positive relationships, whereas "-" indicates significant negative relationships. 


\subsection{Factors Driving Changes in the Four Livestock Species Composition over the Past 40 Years}

Land use policy significantly influenced the change in cattle proportion during 1970-2010 and was also negatively correlated with the change $\left(R^{2}=0.46\right.$, Table 4$)$. Substantial differences existed in the major factors among the three different periods, of which the effect of pastoral population was most important in 1970-1986 $\left(R^{2}=0.40\right)$, whereas a statistically negatively correlation was observed between them in 1987-2000 $\left(R^{2}=0.92\right)$. Lastly, urban population had a leading role for the ecological recovery period $\left(2001-2010, R^{2}=0.76\right)$.

Similarly, urban population was detected as a key factor driving the change in horse composition over the past four decades, with a statistically negative correlation between them $\left(R^{2}=0.87\right.$, Table 4$)$, which indicated that the herders showed a decreasing tendency to keep horses as urbanization in Xilinhot increased over time. The two environmental predictors, mean winter temperature $\left(R^{2}=0.31\right)$ and extremely high temperature $\left(R^{2}=0.44\right)$ were critical factors for the two periods of 1970-1986 and 2001-2010, respectively. In the fast development period, pastoral population had a significant impact on horse composition and was also negatively correlated with it $\left(R^{2}=0.88\right)$.

Changes in both sheep $\left(R^{2}=0.82\right)$ and goat $\left(R^{2}=0.43\right)$ composition were mainly affected by land use policy from 1970 to 2010, which was positively correlated with the two variables (Table 4). For the period of 1970-1986, climate factors were analyzed as major driving forces and R-squared values of non-winter mean temperature and extremely high temperature were $19 \%$ and $43 \%$ for sheep and goat, respectively. The effects of pastoral population on that of sheep $\left(R^{2}=0.83\right)$ and goat $\left(R^{2}=0.93\right)$ were evident between 1987 and 2000, suggesting that the local herders had an increasing shift towards sheep and goat husbandry when the market economy was introduced in Xilinhot during this period. In the ecological recovery period, extremely cold temperature $\left(R^{2}=0.66\right)$ had a dramatic impact on goat composition fluctuation, and winter snowfall $\left(R^{2}=0.16\right)$ was ranked second, showing a statistically negative correlation between them. 
Table 4. Driving force analysis of livestock composition change in three periods during 1970-2010 in Xilinhot, Inner Mongolia, China.

\begin{tabular}{|c|c|c|c|c|c|c|c|c|c|c|c|c|}
\hline \multirow[b]{2}{*}{ Response } & \multicolumn{3}{|c|}{ 1970-1986 } & \multicolumn{3}{|c|}{ 1987-2000 } & \multicolumn{3}{|c|}{ 2001-2010 } & \multicolumn{3}{|c|}{ 1970-2010 } \\
\hline & Predictor & Partial $R^{2}$ & Effect & Predictor & Partial $R^{2}$ & Effect & Predictor & Partial $R^{2}$ & Effect & Predictor & Partial $R^{2}$ & Effect \\
\hline \multirow[t]{2}{*}{ Cattle } & PASPOPU $^{2}$ & $0.40^{* *}$ & + & PASPOPU $^{2}$ & $0.92^{* * *}$ & - & URBPOPU $^{2}$ & $0.76^{* * *}$ & & LANDUC $^{3}$ & $0.46^{* * *}$ & - \\
\hline & & & & WSNOW $^{1}$ & $0.02 *$ & - & NWMTEM $^{1}$ & 0.14 * & + & & & \\
\hline \multirow[t]{3}{*}{ Horse } & WMTEM $^{1}$ & $0.31 *$ & + & PASPOPU $^{2}$ & $0.88^{* * *}$ & - & EXHTEM $^{1}$ & 0.44 * & + & URBPOPU ${ }^{2}$ & $0.87^{* * *}$ & - \\
\hline & WSNOW $^{1}$ & $0.15 *$ & + & & & & & & & LANDUC $^{3}$ & $0.03^{* *}$ & - \\
\hline & & & & & & & & & & PASPOPU $^{2}$ & $0.02^{* *}$ & - \\
\hline \multirow[t]{3}{*}{ Sheep } & NWMTEM $^{1}$ & 0.19 * & + & PASPOPU $^{2}$ & $0.83^{* * *}$ & + & & & & LANDUC $^{3}$ & $0.82^{* * *}$ & + \\
\hline & & & & WMTEM $^{1}$ & 0.06 * & - & & & & PASPOPU $^{2}$ & $0.04^{* *}$ & + \\
\hline & & & & AVTEM $^{1}$ & $0.03 *$ & + & & & & & & \\
\hline \multirow[t]{2}{*}{ Goat } & EXHTEM $^{2}$ & $0.43 * *$ & + & PASPOPU ${ }^{2}$ & $0.93^{* * *}$ & + & EXCTEM $^{1}$ & $0.66^{* *}$ & + & LANDUC $^{3}$ & $0.43^{* * *}$ & + \\
\hline & PASPOPU $^{2}$ & $0.19 *$ & - & URBPOPU $^{2}$ & $0.03^{* *}$ & + & WSNOW $^{1}$ & $0.17^{*}$ & - & EXCTEM $^{1}$ & $0.08^{*}$ & + \\
\hline
\end{tabular}

Regression coefficient is significant ${ }^{*}$ indicates $0.01<p<0.05,{ }^{* *}$ indicates $0.01<p<0.001$ and ${ }^{* * *}$ indicates $\left.p<0.001\right)$, with ${ }^{*}-* * *$ indicating the increasing degrees of statistical significance. The superscript of the predictors, ${ }^{1}$ represents predictors of the environmental aspect; ${ }^{2}$ represents predictors of the socioeconomic aspect; ${ }^{3}$ represents predictors of the local policy aspect. The symbol "+" indicates significant positive relationships, whereas "-" indicates significant negative relationships. 


\section{Discussion}

\subsection{Changes in Livestock Population and Composition}

The total livestock numbers increased markedly over the last 40 years, from 0.6 million sheep units in 1970 to 1.39 million sheep units in 2010, with a minor change in the first period and a radical increase in the last two periods. The overall increasing trend is in agreement with the animal husbandry situation for the study area [26,27]. Previous studies reported a similar trend in Mongolia, which has a similar pastoral system in a similar environment [13,41]. Numerous studies from African countries, however, have documented stagnant or even decreasing trends in livestock number and livestock production [4,42-46]. Livestock report 2006 [42] revealed that Africa relied almost entirely on imports to meet increased domestic demands for livestock products during the late 1990s and early 2000s [43]. Studies in Ethiopia [44,45], the horn of Africa [4], have shown similar decline patterns in livestock numbers and per capita consumption of livestock products in the last 30 years, and others in Botswana [46] have also described a rising and falling pattern in livestock population dynamics, indicating that there is large variation in production levels among developing countries, and some poor countries are barely self-sufficient as a result of fast growth in human population coupled with low livestock productivity [43].

Due to large differences in natural conditions, access to technology, and native cultures [47], pastoral systems differ widely in livestock composition across the world. For example, the main livestock species kept in Africa are cattle, camel, goat, and sheep. Dairy and sheep industries are dominant in South America. In our study site, a multi-species pastoralism involves sheep, goat, cattle, and horse, with a tiny fraction of several draft animals like camel, donkey, and mule, which is also practiced in its adjacent pastoral communities in the Mongolian Plateau $[10,13,48]$. During the past four decades, this region showed a growing tendency to keep more small livestock than large livestock, with a higher proportion of sheep and goat than other species. The proportion of small and large livestock averagely accounted for $64.1 \%$ and $35.9 \%$ of total animals across $1970-2010$, respectively, and the contribution of sheep and goat in head and sheep unit reached $72.9 \%$ and $16.9 \%, 52.9 \%$ and $11.3 \%$, respectively, suggesting that sheep and goat were the most preferable species for local pastoralists and this trend was more aggregated in the last 20 years.

\subsection{Factors Influencing Changes in Livestock Population and Composition During 1970-2010}

Prior studies have revealed that the livestock industry is susceptible to the effects of environmental, social, economic, institutional, and policy factors, which may differ substantially over spatial and temporal scales $[10,19,49,50]$. In our study, the pastoral population significantly impacted the massive increase in livestock population in Xilinhot in the past 40 years, suggesting a heavy dependence of local pastoralists on the animal husbandry for their livelihoods. This finding is consistent with previous studies in this area [29,32] and also congruent with the decisive roles played by livestock and livestock production in many areas and countries of developing world [9,51]. For instance, Staal et al. [52] summarized 92 cases mainly from sub-Saharan Africa and South Asia, showing that the percentage of livestock income from pastoral production in total income averaged 55\%. At the local level, animal husbandry maintains the backbone of Mongolia's economy and nearly half of the total population relies on the livestock sector to varying degrees [41]. In the Inner Mongolia region of China, livestock rearing supports the current 14.4 million pastoralists as their primary livelihood source, with a tiny portion of other revenue income [28]. Strong linkage between population growth and herd expansion emphasizes the importance of herding family size in the extensive pastoral systems. As the number of herding households rises, the animal population will experience a natural increase, potentially creating more intense and acute pressures on the grasslands. Accordingly, the local pastoralists in pastoral regions should be valued and incorporated into the planning and management of rangelands as their crucial element among grassland ecosystems [53]. Otherwise, sustaining grassland functioning and services might not be possible without fully considering pastoral population dynamics. 
During the same period, we also found that the evolving land use policies have greatly contributed to the pastoral development in our study area. In the last nomadic period, many large-scale people's communes aiming at raising agricultural production were established and herders were encouraged to join the communes, which were responsible for managing pastoral lands as well as livestock production [31]. In this period, animal numbers remained constant with a slow growth rate, largely owing to there being no incentive offered by the people's commune to expand herd size or increase livestock productivity [38]. The proportion of large and small animals was virtually equal, accounting for half and half. Apart from providing livestock products for food supply, large livestock were kept mainly for transportation services, including transhumant grazing and transfer between pasturelands and urban areas. It is interesting to note that the high proportion of horse population might be closely related to the military horse farms set up in the 1970s [54], indicating that the national demand would be one of functionalities for livestock to fulfill under the collectivism period.

After the establishment of the Household Production Responsibility System (HPRS) rooted from China's agricultural reform [37] in the 1980s, fundamental transformations in the livestock industry took place, shifting from the collective management to independent family productive units [53], and a transition from a centrally controlled economy to a market economy, as well as a free market mechanism for animal products since the 1990s [55]. This greatly mobilized the herdsmen to raise livestock and stimulated the growth of productivity in the fast development period. The significant relationship between implementation of the HPRS and the radical increase in livestock numbers is also documented in the same area $[31,37,38]$. With the privatization of use right to grasslands and livestock, the pastoralists became settled down and practiced long-year grazing instead of seasonal movements, which facilitated the selection of animal species that were of high value for sale with a small size and faster reproduction rates. The differentiation of animal species was evident at this stage, with the trend of a much higher proportion of small animals than large animals further suggesting that the market forces came into effect in this rapid development stage. This result on driving the changes in livestock composition is similar to studies conducted in Mongolia [13] and is different from that in southern Ethiopia of Africa, where increasing livestock diversification was mainly due to recurring drought, bush invasion, and decreasing adaptability of cattle to the climatic variations [12].

After 2000, large-scale grassland conservation and ecological protection programs supported by the government were carried out by implementing a range of improved grazing systems, such as prohibiting and delaying grazing integrated with ecological subsidy policies, which was to control and alleviate the continued environmental deterioration $[35,38,50]$. As a consequence, the total amount of livestock apparently dropped, especially for small livestock, and the vegetation improved accordingly [27,37]. At the same time, the observed increase in cattle population was not only attributable to the rising domestic demands, but also to policies that changed traditional mobile grazing to stall feeding. Hence, the state policies and regulations associated with environment protection and compensation programs have played a vital role in regulating livestock population and restoring grasslands. More effective and adaptive grazing strategies considering spatial and climatic variability are urgently needed in the future [38].

In addition, climate change represented by annual temperature, extreme low temperature, and drought index had an impact on both the total livestock population and animal species. The snowstorms of 1977 and 1985 [56], as well as the drought during 1999-2001, led to a serious loss for the local animal husbandry, indicating that natural factors, particularly extreme events, were still a major driver for the livestock dynamics in the Xilinhot region. This is also the case in many other arid and semi-arid regions around the world $[12,13,19]$.

\subsection{Implications for Improving Animal Husbandry Sustainability in Xilinhot}

During the past several decades, nomadic pastoralism in Xilinhot has given way to extensive pastoral systems with supplementary feeding. In the mid-1980s, the implementation of land tenure reform and the market economy brought about a short-term boom in local livestock production and 
drove the number of animals to rise substantially. However, the effects of overemphasizing livestock numbers are enormous and destructive, resulting in both degraded grasslands and depauperated herders [50]. These ecological and socioeconomic challenges cannot be dealt with by simply raising the livestock population, which itself has been a source of current problems. More comprehensive strategies based on resilience and sustainability research are needed $[38,57,58]$.

Towards a sustainable animal husbandry in the Xilinhot region, our study has several implications. First, the livelihood strategies of herders need to be diversified, so that livestock rearing will not be their only income source. This is necessary for both improving pastoralist welfare and restoring the degraded grasslands. It requires government subsidies and policy support. Ecologically friendly urbanization can help provide more diversified jobs, as well as education and vocational training opportunities. This can significantly reduce the pressures of grassland utilization simply for livelihoods. Second, future policies need to place more emphasis on increasing livestock production efficiency than livestock numbers, which will help enhance the productivity while decreasing the animal population associated with the labor and financial inputs [28]. Third, incentive systems are needed to encourage and reward herders to utilize grassland resources properly and to restore degraded grasslands. The central and local governments need to establish rigorous policies and regulations for ecological protection and compensation. Finally, governmental policies should encourage collective action and cooperation $[59,60]$, especially in remote places. Small household herders scatter in remote places, and thus are vulnerable (and less resilient) to environmental and economic shocks because of their geographic isolation and technological disadvantages. In general, herders can work together to increase economic and ecological efficiencies by increasing their social capital [31].

\section{Conclusions}

The Xilinhot grassland has witnessed substantial environmental and socioeconomic transformations during the past four decades, resulting in dramatic changes in livestock numbers and composition. Our study revealed that in the past 20 years, socioeconomic factors have played a much stronger role than environmental ones in driving the livestock dynamics. Growing pastoral population, land use policy, and the conservation programs initiated by the central government have contributed significantly to the current pattern of livestock production. To improve both the degraded grassland ecosystems and herders' wellbeing in the region, policies and regulations are needed to promote sustainable animal husbandry. These policies ought to focus on diversifying livelihood strategies and income sources, increasing livestock production efficiency, establishing incentive systems to encourage and reward sustainable use of grasslands, and encouraging collective action and cooperation to enhance herders' social capital and resilience.

Author Contributions: J.W. and Y.J. conceived and designed the study; Y.J. performed the data collection and analyzed the data; Y.J. prepared the draft manuscript and was involved in paper revision; Q.Z. and J.N. helped with data collection and analysis, as well as manuscript revision; J.W. helped with the preparation and revision of the manuscript.

Funding: This research received no external funding.

Acknowledgments: We are grateful to Academic Editor and three anonymous reviewers for their invaluable comments and helpful suggestions. We would like to thank Yang Wang, Zhichun Lan and Xiaoming Lu for their help with data analysis and manuscript preparation.

Conflicts of Interest: The authors declare no conflict of interest.

\section{References}

1. $\mathrm{Xu}, \mathrm{G} . ; \mathrm{Wu}, \mathrm{J}$. Social-ecological transformations of Inner Mongolia: A sustainability perspective. Ecol. Process. 2016, 5, 23. [CrossRef]

2. Paul, R. The social impact of livestock: A developing country perspective. Anim. Sci. J. 2003, 74, $245-253$.

3. Steinfeld, H.; Mooney, H.A.; Schneider, F.; Neville, L.E. Livestock in a Changing Landscape, Volume 1: Drivers, Consequences and Responses; Island: Washington, DC, USA, 2010. 
4. Gerber, P.; Mooney, H.A.; Dijkman, J.; Tarawali, S.; Haan, C.D. Livestock in a Changing Landscape, Volume 2: Experiences and Regional Perspectives; Island: Washington, DC, USA, 2010.

5. Rosegrant, M.W.F.M.; Sinha, A.; Alder, J.; Ahammad, H.; de Fraiture, C.; Eickhour, B.; Fonseca, J.; Huang, J.; Koyama, O.; Omezzine, A.M.; et al. Looking into the future for agriculture and AKST (Agricultural Knowledge Science and Technology). In Agriculture at a Crossroads; Island Press: Washington, DC, USA, 2009; pp. 307-376.

6. Hurst, P.; Termine, P.; Karl, M. Agricultural Workers and Their Contribution to Sustainable Agriculture and Rural Development; Food and Agriculture Organization: Rome, Italy, 2005.

7. Reynolds, C.; Crompton, L.; Mills, J. Livestock and climate change impacts in the developing world. Outlook Agric. 2010, 39, 245-248. [CrossRef]

8. Thornton, P.K.; van de Steeg, J.; Notenbaert, A.; Herrero, M. The impacts of climate change on livestock and livestock systems in developing countries: A review of what we know and what we need to know. Agric. Syst. 2009, 101, 113-127. [CrossRef]

9. Herrero, M.; Grace, D.; Njuki, J.; Johnson, N.; Enahoro, D.; Silvestri, S.; Rufino, M.C. The roles of livestock in developing countries. Animal 2013, 7, 3-18. [CrossRef]

10. Hilker, T.; Natsagdorj, E.; Waring, R.H.; Lyapustin, A.; Wang, Y.J. Satellite observed widespread decline in Mongolian grasslands largely due to overgrazing. Glob. Chang. Biol. 2014, 20, 418-428. [CrossRef]

11. Moore, A.D.; Ghahramani, A. Climate change and broadacre livestock production across southern Australia. 1. Impacts of climate change on pasture and livestock productivity, and on sustainable levels of profitability. Glob. Chang. Biol. 2013, 19, 1440-1455. [CrossRef]

12. Megersa, B.; Markemann, A.; Angassa, A.; Ogutu, J.; Piepho, H.-P.; Valle Zárate, A. Livestock Diversification: An Adaptive Strategy to Climate and Rangeland Ecosystem Changes in Southern Ethiopia. Hum. Ecol. 2014, 42, 509-520. [CrossRef]

13. Shabb, D.; Chitnis, N.; Baljinnyam, Z.; Saagii, S.; Zinsstag, J. A mathematical model of the dynamics of Mongolian livestock populations. Livest. Sci. 2013, 157, 280-288. [CrossRef]

14. Herrero, M.; Thornton, P.K.; Gerber, P.; Reid, R.S. Livestock, livelihoods and the environment: Understanding the trade-offs. Curr. Opin. Environ. Sustain. 2009, 1, 111-120. [CrossRef]

15. Hopkins, A.; Del Prado, A. Implications of climate change for grassland in Europe: Impacts, adaptations and mitigation options: A review. Grass Forage Sci. 2007, 62, 118-126. [CrossRef]

16. Sirohi, S.; Michaelowa, A. Sufferer and cause: Indian livestock and climate change. Clim. Chang. 2007, 85, 285-298. [CrossRef]

17. Baylis, M.; Githeko, A.K. The Effects of Climate Change on Infectious Diseases of Animals. In Report for the Foresight Project on Detection of Infectious Diseases, Department of Trade and Industry, UK Government; Office of Science and Innovation: London, UK, 2006; p. 35.

18. IPCC (Intergovernmental Panel on Climate Change). Climate Change 2007: Impacts, Adaptation and Vulnerability. Summary for Policy Makers. 2007. Available online: https:/www.ipcc.ch/site/assets/uploads/ 2018/02/ar4-wg2-spm-1.pdf (accessed on 23 January 2008).

19. Li, A.; Chen, S.; Zhang, X.; Huang, J. Political Pressures Increased Vulnerability to Climate Hazards for Nomadic Livestock in Inner Mongolia, China. Sci. Rep. 2017, 7. [CrossRef] [PubMed]

20. Steinfeld, H.; Wassenaar, T.; Jutzi, S. Livestock production systems in developing countries: Status, drivers, trends. Rev. Sci. Tech. 2006, 25, 505-516. [CrossRef] [PubMed]

21. Saizen, I. Change in Livestock Species and Their Spatial Distribution. In The Mongolian Ecosystem Network; Yamamura, N., Fujita, N., Maekawa, A., Eds.; Springer: Tokyo, Japan, 2013; pp. 215-232.

22. Li, X.L.; Yuan, Q.H.; Wan, L.Q.; He, F. Perspectives on livestock production systems in China. Rangel. J. 2008, 30, 211-220. [CrossRef]

23. Caraveli, H. A comparative analysis on intensification and extensification in mediterranean agriculture: Dilemmas for LFAs policy. J. Rural Stud. 2000, 16, 231-242. [CrossRef]

24. Du, F.; Cao, Q. Eco-husbandry: Trends of Animal Husbandry Economy in West China Prairies. J. Orig. Ecol. Natl. Cult. 2012, 4, 118-127. (In Chinese)

25. Dong, X.; Zhang, X. The Grassland in the Inner Mongolia is Overloaded and Changes of the Production Pattern are Highlighted. Resour. Sci. 2005, 27, 175-179. (In Chinese) 
26. Cui, X.; Guo, K.; Hao, Y.; Chen, Z. Degradation and Management of Steppes in China. In Eurasian Steppes. Ecological Problems and Livelihoods in a Changing World; Werger, M.J.A., van Staalduinen, M.A., Eds.; Springer: Hague, The Netherlands, 2012; Volume 6, pp. 475-490.

27. Li, S.; Verburg, P.; Lv, S.; Wu, J.; Li, X. Spatial analysis of the driving factors of grassland degradation under conditions of climate change and intensive use in Inner Mongolia, China. Reg. Environ. Chang. 2011, 12, 1-14. [CrossRef]

28. Briske, D.D.; Zhao, M.L.; Han, G.D.; Xiu, C.B.; Kemp, D.R.; Willms, W.; Havstad, K.; Kang, L.; Wang, Z.W.; $\mathrm{Wu}$, J.G.; et al. Strategies to alleviate poverty and grassland degradation in Inner Mongolia: Intensification vs production efficiency of livestock systems. J. Environ. Manag. 2015, 152, 177-182. [CrossRef]

29. Wu, J.; Loucks, O. Xilingele (The Xilingol Grassland). In Grasslands and Grassland Sciences in Northern China; The US National Research Council, Ed.; National Academy Press: Washington, DC, USA, 1992; pp. 67-84.

30. Xia, X.; Li, B.; Sui, Y. Analysis of Regional Differentiation of Animal Husbandry Production Structure in China from the Perspectives of Resources Endowment and Food Security. Resour. Sci. 2010, 32, 1592-1600. (In Chinese)

31. Li, W.J.; Ali, S.H.; Zhang, Q. Property rights and grassland degradation: A study of the Xilingol Pasture, Inner Mongolia, China. J. Environ. Manag. 2007, 85, 461-470.

32. Xu, G.C.; Kang, M.Y.; Jiang, Y. Adaptation to the Policy-oriented Livelihood Change in Xilingol Grassland, Northern China. Procedia Environ. Sci. 2012, 13, 1668-1683. [CrossRef]

33. Humphrey, C.; Sneath, D. The End of Nomadism? Society, State, and the Environment in Inner Asia; Duke University Press: Durham, NC, USA, 1999.

34. Li, O.; Ma, R.; Simpson, J.R. Changes in the nomadic pattern and its impact on the Inner Mongolian steppe grasslands ecosystem. Nomadic Peoples 1993, 33, 63-72.

35. Shao, L.Q.; Chen, H.B.; Zhang, C.; Huo, X.X. Effects of Major Grassland Conservation Programs Implemented in Inner Mongolia since 2000 on Vegetation Restoration and Natural and Anthropogenic Disturbances to Their Success. Sustainability 2017, 9, 466. [CrossRef]

36. Jiang, H. Grassland management and views of nature in China since 1949: Regional policies and local changes in Uxin Ju, inner Mongolia. Geoforum 2005, 36, 641-653. [CrossRef]

37. Li, A.; Wu, J.; Huang, J. Distinguishing between human-induced and climate-driven vegetation changes: A critical application of RESTREND in inner Mongolia. Landsc. Ecol. 2012, 27, 969-982. [CrossRef]

38. Hua, L.; Squires, V.R. Managing China's pastoral lands: Current problems and future prospects. Land Use Policy 2015, 43, 129-137. [CrossRef]

39. Department of Animal Husbandry and Veterinary; General Station of Animal Husbandry and Veterinary of Ministry of Agriculture of China. Rangeland Resources of China; China Science \& Technology Press: Beijing, China, 1996. (In Chinese)

40. Shan, Y.M.; Chen, D.M.; Guan, X.X.; Zheng, S.X.; Chen, H.J.; Wang, M.J.; Bai, Y.F. Seasonally dependent impacts of grazing on soil nitrogen mineralization and linkages to ecosystem functioning in Inner Mongolia grassland. Soil Biol. Biochem. 2011, 43, 1943-1954. [CrossRef]

41. Johnson, D.A.; Sheehy, D.P.; Miller, D.; Damiran, D. Mongolian rangelands in transition. Secheresse 2006, 17, 133-141.

42. Steinfeld, H.; Costales, A.; Rushton, J.; Scherf, B.; Bennett, T.; Hall, D. Livestock Report 2006; FAO: Rome, Italy, 2006. Available online: http://www.fao.org/3/a0255e/a0255e00.htm (accessed on 11 March 2011).

43. FAO. World Livestock 2011: Livestock in Food Security; FAO: Rome, Italy, 2011.

44. Jabbar, M.A.; Ahmed, M.; Benin, S.; Gebremedhin, B.; Ehui, S. Livestock, livelihood and land management issues in the highlands of Ethiopia. In Policies for Sustainable Land Management in the East African Highlands: Summary of Papers and Proceedings of a Conference Held at the United Nations Economic Commission for Africa (UNECA), Addis Ababa, Ethiopia, 24-26 April 2002; Benin, S., Pender, J., Ehui, S., Eds.; IFPRI: Washington, DC, USA, 2003; pp. 87-93.

45. Halderman, M. The Political Economy of Pro-Poor Livestock Policy-making in Ethiopia. PPLPI Working Paper no. 19. In Pro-Poor Livestock Policy Initiative; FAO: Rome, Italy, 2005.

46. Kgosikoma, O.E.; Batisani, N. Livestock population dynamics and pastoral communities' adaptation to rainfall variability in communal lands of Kgalagadi South, Botswana. Pastoralism 2014, 4, 19. [CrossRef]

47. Verburg, P.H.; Keulen, H.V. Exploring changes in the spatial distribution of livestock in China. Agric. Syst. 1999, 62, 51-67. [CrossRef] 
48. Sneath, D. Ecology-State policy and pasture degradation in inner Asia. Science 1998, 281, 1147-1148. [CrossRef]

49. Mwanyumba, P.M.; Wahome, R.W.; MacOpiyo, L.; Kanyari, P. Livestock herd structures and dynamics in Garissa County, Kenya. Pastoralism 2015, 5, 26. [CrossRef]

50. Han, J. Survey on Ecological Issues of China's Grasslands; Shanghai Far East Publishers: Shanghai, China, 2011. (In Chinese)

51. Davis, B.; Winters, P.; Carletto, G.; Covarrubias, K.; Quinones, E.; Zezza, A.; Stamoulis, K.; Bonomi, G.; Di Giuseppe, S. Rural Income Generating Activities: A Cross-Country Comparison. ESA Working Paper; FAO: Rome, Italy, 2007.

52. Staal, S.J.; Poole, J.; Baltenweck, I.; Mwacharo, J.; Notenbaert, A.M.O.; Randolph, T.F.; Thorpe, W.; Nzuma, J.; Herrero, M. Strategic Investment in Livestock Development as a Vehicle for Rural Livelihoods; Bill and Melinda Gates Foundation-ILRI Knowledge Generation Project Report; International Livestock Research Institute: Nairobi, Kenya, 2009; p. 78.

53. Neupert, R.F. Population, Nomadic Pastoralism and the Environment in the Mongolian Plateau. Popul. Environ. 1999, 20, 413-441. [CrossRef]

54. Wu, J.; Zhang, Q.; Li, A.; Liang, C. Historical landscape dynamics of Inner Mongolia: Patterns, drivers, and impacts. Landsc. Ecol. 2015, 30, 1579-1598. [CrossRef]

55. Yin, Y.; Hou, X.; Ding, Y.; Han, Y. Response of animal husbandry to climate change in desert steppe-A case of Suniteyou Banner, Inner Mongolia. J. Arid Land Resour. Environ. 2012, 26, 153-160. (In Chinese)

56. Editorial Committee of Xilingol Meng Chorography (ECXMC). Xilingol Meng Chorography; Inner Mongolia People's Press: Hohhot, China, 1996. (In Chinese)

57. Dong, S. Overview: Pastoralism in the World. In Building Resilience of Human-Natural Systems of Pastoralism in the Developing World: Interdisciplinary Perspectives; Dong, S., Kassam, K.-A.S., Tourrand, J.F., Boone, R.B., Eds.; Springer International Publishing: Cham, Switzerland, 2016; pp. 1-37.

58. Wu, J.G. Landscape sustainability science: Ecosystem services and human well-being in changing landscapes. Landsc. Ecol. 2013, 28, 999-1023. [CrossRef]

59. Ostrom, E. A behavioral approach to the rational choice theory of collective action. Am. Political Sci. Rev. 1998, 92, 1-22. [CrossRef]

60. Levin, S. Crossing scales, crossing disciplines: Collective motion and collective action in the Global Commons. Philos. Trans. R. Soc. B Biol. Sci. 2010, 365, 13-18. [CrossRef] 